OPEN ACCESS

Edited by: Jutta Eichler,

Friedrich-Alexander-Universität Erlangen-Nürnberg, Germany

Reviewed by:

Lihua Yuan,

Sichuan University, China

Cheng Yang,

Sichuan University, China

*Correspondence:

Stefano Pieraccini

stefano.pieraccini@ununimi.it

Andrea Pinto

andrea.pinto@unimi.it

Sara Pellegrino

sara.pellegrino@unimi.it

Specialty section: This article was submitted to

Supramolecular Chemistry,

a section of the journal

Frontiers in Chemistry

Received: 29 November 2018

Accepted: 20 February 2019

Published: 18 March 2019

Citation:

Oliva F, Bucci R, Tamborini L, Pieraccini S, Pinto A and Pellegrino S (2019) Bicyclic Pyrrolidine-Isoxazoline $\gamma$ Amino Acid: A Constrained Scaffold for Stabilizing $\alpha$-Turn Conformation in Isolated Peptides.

Front. Chem. 7:133.

doi: 10.3389/fchem.2019.00133

\section{Bicyclic Pyrrolidine-Isoxazoline $\gamma$ Amino Acid: A Constrained Scaffold for Stabilizing $\alpha$-Turn Conformation in Isolated Peptides}

\author{
Francesco Oliva ${ }^{1}$, Raffaella Bucci ${ }^{2}$, Lucia Tamborini ${ }^{2}$, Stefano Pieraccini ${ }^{1 *}$, Andrea Pinto ${ }^{3 *}$ \\ and Sara Pellegrino ${ }^{2 *}$
}

${ }^{1}$ Department of Chemistry, University of Milan, Milan, Italy, ${ }^{2}$ Department of Pharmaceutical Sciences, University of Milan, Milan, Italy, ${ }^{3}$ Department of Food, Environmental and Nutritional Sciences, University of Milan, Milan, Italy

Unnatural amino acids have tremendously expanded the folding possibilities of peptides and peptide mimics. While $\alpha, \alpha$-disubstituted and $\beta$-amino acids are widely studied, $\gamma$-derivatives have been less exploited. Here we report the conformational study on the bicyclic unnatural $\gamma$ amino acid, 4,5,6,6a-tetrahydro-3aH-pyrrolo[3,4-d]isoxazole-3-carboxylic acid 1. In model peptides, the $(+)-(3 a R 6 a S)$-enantiomer is able to stabilize $\alpha$-turn conformation when associated to glycine, as showed by ${ }^{1} \mathrm{H}-\mathrm{NMR}$, FT-IR, and circular dichroism experiments, and molecular modeling studies. $\alpha$-turn is a structural motif occurring in many biologically active protein sites, although its stabilization on isolated peptides is quite uncommon. Our results make the unnatural $\gamma$-amino acid $\mathbf{1}$ of particular interest for the development of bioactive peptidomimetics.

Keywords: unnatural $\gamma$-amino acids, peptidomimetic, isoxazoline, $\alpha$-turn, metadynamic studies, conformational analysis

\section{INTRODUCTION}

Amino acids are the key building blocks of proteins and biomolecules and are widely exploited in different applications, from pharmaceutical chemistry and biomedicine to material science, optoelectronics and catalysis (Zhang et al., 2012; Mikhalevich et al., 2017; Solomon et al., 2017; López-Andarias et al., 2018; Raymond and Nilsson, 2018). The insertion of unnatural amino acids (UAAs) in peptides and peptide mimics could add specific features to these molecules, such as proteolytic stability, active functional groups and new reactivity (Clerici et al., 2016; Pellegrino et al., 2016, 2017; Bucci et al., 2017). $\alpha$, $\alpha$ disubstituted and $\beta$ - homologs of natural amino acids have been particularly studied during the years for their ability to introduce conformational constrains in peptides and to stabilize specific secondary structures (Bonetti et al., 2015; Pellegrino et al., 2015; Fanelli et al., 2017; Kobayashi et al., 2017). On the other hand, $\gamma$ UAAs provide a further opportunity to engineer the available backbone through the incorporation of an additional methylene group 
(Vasudev et al., 2011; Sohora et al., 2018). Recent studies report that $\gamma$-peptides are able to form helices, sheets and turns, whose conformational stability is increased by introducing substituents on the backbone chain (Bouillère et al., 2011). Moreover, cyclic $\gamma$ UAAs, as gabapentin (Gpn) (Chatterjee et al., 2009; Konda et al., 2018) and $\gamma$-cyclohexyl amino acid (Guo et al., 2012) are able to stabilize both turn and helix conformation in oligomers and in mixed $\alpha-\gamma$ and $\beta-\gamma$ sequences. On the other hand, the use of bicyclic $\gamma$ amino acids for the stabilization of the peptide structure is much less investigated (Machetti et al., 2000).

In this work, we investigated the conformational behavior of both the enantiomers of the bicyclic unnatural $\gamma$ amino acid 4,5,6,6a-tetrahydro-3aH-pyrrolo[3,4- $d]$ isoxazole-3-carboxylic acid 1, obtained starting from the corresponding ethyl esters recently described by us (Tamborini et al., 2015). Compound $\mathbf{1}$ is a conformationally constrained dipeptide analog and, in principle, it could substitute two amino acids in a peptide chain. The presence of the constrained bicyclic system could induce specific secondary structure allowing a proper orientation of the peptide arms at $\mathrm{C}$ - and $\mathrm{N}$ - termini. Furthermore, the presence of the isoxazoline ring, a core often found in biologically active compounds, could be particularly useful for future applications in the pharmaceutical field. In fact, isoxazoline derivatives are important scaffolds found in many naturally occurring and biologically active compounds possessing a wide range of bioactivities, such as antibacterial, antifungal, antiparasitic (Conti et al., 2011; Bruno et al., 2014; Pinto et al., 2016a), anticancer (Castellano et al., 2011; Kaur et al., 2014), anti-inflammatory and anticonvulsant activity (Sperry and Wright, 2005; Pinto et al., 2011, 2016b). Isoxazolines are also considered to be important precursors for the synthesis of $\beta$-hydroxyketones (Kozikowski and Park, 1990; Tsantali et al., 2007), $\beta$-aminoalcohols (Fuller et al., 2005), isoxazolidines (Itoh et al., 2002), and many other valuable compounds. Recently, peptidomimetics containing the isoxazoline ring have been reported as $\beta$-turn mimics (Bucci et al., 2018; Memeo et al., 2018).

Starting from the (-)-(3aS6aR)-1 and (+)-(3aR6aS)-1 enantiomers, model peptides containing Leu-Val dipeptide at $C$-terminus and variable sequences at $N$-terminus were prepared. Their conformational behavior was investigated by NMR spectroscopy, FT-IR, circular dichroism, and molecular modeling. Our results indicated that $(+)-(3 \mathrm{a} R 6 \mathrm{a} S)-\mathbf{1}$ enantiomer, in combination with glycine, is effective in stabilizing the $\alpha$-turn conformation in peptides (Figure 1). This structural motif occurs quite often in many key sites of proteins, such as enzyme active site, and metal binding domains (Wintjens et al., 1996), although few molecules are known to mimic or stabilize it on isolated peptides (Kelso et al., 2004; Hoang et al., 2011; Krishna et al., 2014; Wang et al., 2018.). Our results make thus the unnatural $\gamma$-amino acid 1 of particular interest for future development of bioactive peptidomimetics.

Abbreviations: ACN, Acetonitrile; Boc, tert-butyloxycarbonyl; DIEA, N,N-Diisopropylethylamine; DMF, Dimethylformamide; EDC, 1-Ethyl-3-(3dimethylaminopropyl)carbodiimide; Gly, Glycine; HOBt, Hydroxybenzotriazole; Leu, Leucine; Phe, Phenylalanine; TFA, Trifluoroacetic acid; Val, Valine.

\section{MATERIALS AND METHODS}

\section{Materials}

Chemicals were obtained from Zentek (Italy) and used without further purification. Melting points were determined in a Stuart Scientific melting point apparatus in open capillary tubes and are certified. ESI mass spectra were recorded on an LCQESI. MS was recorded on a LCQ Advantage spectrometer from Thermo Finningan and a LCQ Fleet spectrometer from Thermo Scientific. CD experiments were carried out on a Jasco J-810 instrument. Spectra were obtained from 195 to $250 \mathrm{~nm}$ with a $0.1 \mathrm{~nm}$ step and $1 \mathrm{~s}$ collection time per step, taking three averages. The CD spectra were plotted as mean residue ellipticity $\theta$ (degree $\times$ $\left.\mathrm{cm}^{2} \times \mathrm{dmol}^{-1}\right)$ vs. wave length $\lambda(\mathrm{nm})$. Noise-reduction was obtained using a Fourier-transform filter program from Jasco. The NMR spectroscopic experiments were carried out on a Varian OXFORD $300 \mathrm{MHz}\left(300\right.$ and $75 \mathrm{MHz}$ for ${ }^{1} \mathrm{H}$ and ${ }^{13} \mathrm{C}$, respectively). Chemical shifts, $\delta$, are given in $\mathrm{ppm}$ relative to the $\mathrm{CHCl}_{3}$ internal standard, and the coupling constants, $J$, are reported in hertz $(\mathrm{Hz})$.

\section{Methods}

\section{Synthesis of $(-)-(3 a S, 6 a R)-1$ and $(+)-(3 a R, 6 a S)-1$}

Compound (-)-2 or (+)-2 (200 mg, $0.70 \mathrm{mmol})$ was dissolved in $\mathrm{MeOH}(3.0 \mathrm{~mL})$ and treated with $1 \mathrm{~N} \mathrm{NaOH}$ aqueous solution $(1.4 \mathrm{~mL})$. The mixture was stirred at room temperature for $1 \mathrm{~h}$ and the disappearance of the starting material was monitored by TLC (Cyclohexane/EtOAc 7:3). The mixture was diluted in water $(20 \mathrm{~mL})$, made acidic with $2 \mathrm{~N}$ aqueous $\mathrm{HCl}$ and extracted with EtOAc. The organic phase was dried over anhydrous $\mathrm{Na}_{2} \mathrm{SO}_{4}$ and after evaporation of the solvent, the acid derivate (-)-(3aS,6aR)-1 or (+)-(3aR,6aS)-1 (170 mg, 95\%) was obtained as a white solid.

(-)-(3aS,6aR)-1: $\mathrm{R}_{f}\left(\mathrm{CH}_{2} \mathrm{Cl}_{2} / \mathrm{MeOH} 9: 1+1 \% \mathrm{AcOH}\right): 0.40$; $[\alpha]_{\mathrm{D}}^{20}:(-) 192.2(\mathrm{c}: 0.55$ in $\mathrm{MeOH}) ; \mathrm{mp}=\operatorname{dec} . \mathrm{T}>137^{\circ} \mathrm{C} ;{ }^{1} \mathrm{H}$ NMR (300 MHz, CD 3 OD): $\delta 5.35$ (dd, $J=4.8,9.2,1 \mathrm{H}) ; 4.10$ (ddd, $J=2.2,9.2,9.2,1 \mathrm{H}) ; 3.86-3.96(\mathrm{~m}, 2 \mathrm{H}) ; 3.38-3.50(\mathrm{~m}, 2 \mathrm{H})$; 1.44 (s, 9H) ppm; ${ }^{13} \mathrm{C} \mathrm{NMR}\left(75 \mathrm{MHz}, \mathrm{CD}_{3} \mathrm{OD}\right): \delta 161.28,154.77$, $152.95,87.62,80.33,53.06,50.93,49.10,27.12$ (3C) ppm.

HRMS (ESI) $[\mathrm{M}+\mathrm{Na}]^{+}$calculated for $\mathrm{C}_{11} \mathrm{H}_{16} \mathrm{~N}_{2} \mathrm{O}_{5} \mathrm{Na}$ : 279.0957, found: 279.0950 .

$(+)-(3 a R, 6 a S)-1:[\alpha]_{D}^{20}:(+) 192.5($ c: 0.57 in $\mathrm{MeOH})$.

\section{General Procedure for Coupling Reaction}

Free carboxylic acid (1 equiv.) was dissolved in $\mathrm{CH}_{2} \mathrm{Cl}_{2}(0.01 \mathrm{M}$ solution) and the mixture was cooled to $0^{\circ} \mathrm{C}$. $\mathrm{HOBt}(1.1$ equiv.) and EDC (1.1 equiv.) were added. After $1 \mathrm{~h}$, free amino compound (1 equiv.) was added, followed by the addition of DIEA (2 equiv.). The reaction mixture was stirred at room temperature for 24 overnight (TLC analysis). The organic layer was washed with a $5 \%$ solution of $\mathrm{KHSO}_{4}$ (3 times), with a saturated solution of $\mathrm{NaHCO}_{3}$ (3 times) and with brine (1 time). The organic phase was dried over $\mathrm{Na}_{2} \mathrm{SO}_{4}$ and the solvent was removed under vacuum. The products were purified by column flash chromatography on silica gel (hexane/ethyl acetate gradient) followed by a crystallization from a mixture of ethyl acetate/hexane. 


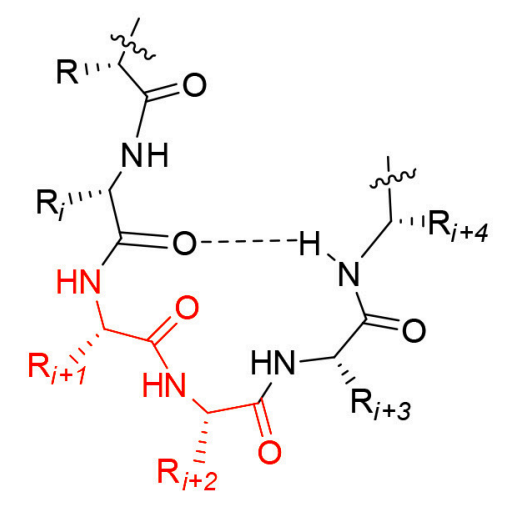

$\alpha$-turn

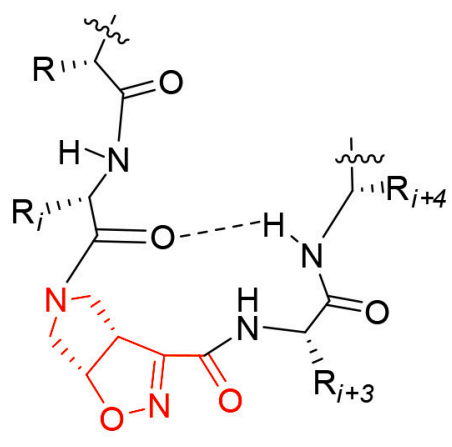

$\alpha$-turn mimic

FIGURE 1 | Natural $\alpha$-turn and the proposed $\alpha$-turn mimic containing the bicyclic pyrrolidine-isoxazoline $\gamma$ amino acid.

\begin{tabular}{lccc}
\hline Product & Yield (\%) & Product & Yield (\%) \\
\hline N-Boc-Leu-Val-CONH 2 & 96 & $\mathbf{8}$ & 77 \\
$\mathbf{4}$ & 65 & $\mathbf{9}$ & 80 \\
$\mathbf{5}$ & 63 & $\mathbf{1 0}$ & 65 \\
\hline
\end{tabular}

asee Steinke and Kula (1990).

$\mathrm{N}$-Boc-(-)- $\Delta^{2}$-isox-Leu-Val-CONH${ }_{2}$ (4)

${ }^{1} \mathrm{H}$ NMR $\left(300 \mathrm{MHz}, \mathrm{CDCl}_{3}\right): \delta 7.11(\mathrm{bs}, 1 \mathrm{H}), 6.88(\mathrm{~d}, J=8.8 \mathrm{~Hz}$, $1 \mathrm{H}), 6.19$ (bs, $1 \mathrm{H}), 5.72$ (bs, $1 \mathrm{H}), 5.34-5.29$ (m, $1 \mathrm{H}), 4.56-4.48$ $(\mathrm{m}, 1 \mathrm{H}), 4.31(\mathrm{dd}, J=8.2 ; 6.9 \mathrm{~Hz}, 1 \mathrm{H}), 4.17-3.83(\mathrm{~m}, 3 \mathrm{H}), 3.56-$ $3.42(\mathrm{~m}, 2 \mathrm{H}), 2.23-2.07(\mathrm{~m}, 1 \mathrm{H}), 1.85-1.61(\mathrm{~m}, 3 \mathrm{H}), 1.43(\mathrm{~s}, 9 \mathrm{H})$, $0.99-0.92(\mathrm{~m}, 12 \mathrm{H}) \mathrm{ppm}$.

${ }^{13} \mathrm{C}$ NMR $\left(75 \mathrm{MHz}, \mathrm{CDCl}_{3}\right): \delta 173.04,171.32,159.44,154.28$, $153.93,87.40,80.43,58.24,53.26,52.30,50.53,49.32,40.87,30.53$, $28.31,24.82,22.91,21.92,19.27,17.93 \mathrm{ppm}$.

HRMS (ESI) $[\mathrm{M}+\mathrm{Na}]^{+}$calculated for $\mathrm{C}_{22} \mathrm{H}_{37} \mathrm{~N}_{5} \mathrm{O}_{6} \mathrm{Na}$ : 490.2642, found: 490.2635 .

\section{N-Boc- (+)- $\Delta^{2}$-isox-Leu-Val-CONH 2 (5)}

${ }^{1} \mathrm{H} \mathrm{NMR}\left(300 \mathrm{MHz}, \mathrm{CDCl}_{3}\right): \delta 7.05$ (bs, $\left.1 \mathrm{H}\right), 6.73(\mathrm{~d}, J=7.9 \mathrm{~Hz}$, $1 \mathrm{H}), 6.13$ (bs, $1 \mathrm{H}), 5.69(\mathrm{bs}, 1 \mathrm{H}), 5.37-5.28(\mathrm{~m}, 1 \mathrm{H}), 4.56-4.47(\mathrm{~m}$, $1 \mathrm{H}), 4.36-4.27(\mathrm{~m}, 1 \mathrm{H}), 4.18-4.07(\mathrm{~m}, 1 \mathrm{H}), 3.99-3.77(\mathrm{~m}, 2 \mathrm{H})$, 3.61-3.41 (m, 2H), 2.28-2.10 (m, 1H), 1.78-1.57(m, 3H), 1.49 (s, $9 \mathrm{H}), 1.01-0.90(\mathrm{~m}, 12 \mathrm{H}) \mathrm{ppm}$.

${ }^{13} \mathrm{C}$ NMR $\left(75 \mathrm{MHz}, \mathrm{CDCl}_{3}\right): \delta 173.16,171.54,159.33,154.16$, $153.96,80.34,60.38,58.16,53.27,52.25,49.41,41.02,30.67,28.32$, 24.83, 22.87, 21.99, 19.20, $18.02 \mathrm{ppm}$.

HRMS (ESI) $[\mathrm{M}+\mathrm{Na}]^{+}$calculated for $\mathrm{C}_{22} \mathrm{H}_{37} \mathrm{~N}_{5} \mathrm{O}_{6} \mathrm{Na}$ : 490.2642, found: 490.2635 .

\footnotetext{
NH-Boc-Phe-(-)- $\Delta^{2}$-isox-Leu-Val-CONH 2 (8)-Mixture of two conformers-

${ }^{1} \mathrm{H}$ NMR $\left(300 \mathrm{MHz}, \mathrm{CDCl}_{3}\right): \delta$ 7.36-7.16 (m, 5H), 7.15-7.08 (m, $1 \mathrm{H}), 7.05-6.97(\mathrm{~m}, 1 \mathrm{H}), 6.88-6.77(\mathrm{~m}, 1 \mathrm{H}), 6.05$ (bs, $1 \mathrm{H}), 5.71$ (bs, $1 \mathrm{H}), 5.43(\mathrm{~d}, J=8.4 \mathrm{~Hz} 1 \mathrm{H}), 5.33-5.22(\mathrm{~m}, 3 \mathrm{H}), 5.09-4.9(\mathrm{~m}$, $1 \mathrm{H}), 4.64-4.44(\mathrm{~m}, 3 \mathrm{H}), 4.33-4.23(\mathrm{~m}, 2 \mathrm{H}), 4.17-4.03(\mathrm{~m}, 2 \mathrm{H})$,
}

3.99-3.91 (m, 1H), 3.87-3.75(m, 2H), 3.70-3.50 (m, 2H), 3.42$3.30(\mathrm{~m}, 1 \mathrm{H}), 3.13-3.03(\mathrm{~m}, 1 \mathrm{H}), 2.97-2.74(\mathrm{~m}, 3 \mathrm{H}), 2.51(\mathrm{dd}, J$ $=12.2 ; 4.8 \mathrm{~Hz}, 1 \mathrm{H}), 2.21-2.05(\mathrm{~m}, 1 \mathrm{H}), 1.51-1.33(\mathrm{~m}, 9 \mathrm{H}), 1.06-$ $0.84(\mathrm{~m}, 12 \mathrm{H}) \mathrm{ppm}$.

${ }^{13} \mathrm{C} \mathrm{NMR}\left(75 \mathrm{MHz}, \mathrm{CDCl}_{3}\right): \delta 172.91,171.38,170.09,159.11$, $157.88,157.30,153.83,152.33,136.34,129.46,129.30,128.56$, $128.44,127.12,126.85,96.33,87.21,85.98,58.09,53.31,52.77$, $52.36,50.95,49.64,49.00,48.59,41.05,40.91,30.83,30.62,29.69$, 28.35, 24.84, 22.81, 22.71, 19.18, 17.94 ppm.

HRMS (ESI) $[\mathrm{M}+\mathrm{Na}]^{+}$calculated for $\mathrm{C}_{31} \mathrm{H}_{46} \mathrm{~N}_{6} \mathrm{O}_{7} \mathrm{Na}$ : 637.3326, found: 637.3332 .

\section{$\mathrm{NH}$-Boc-Phe-(+)- $\Delta^{2}$-isox-Leu-Val-CONH 2 (9)-Mixture of two conformers-}

${ }^{1} \mathrm{H}$ NMR (300 MHz, $\left.\mathrm{CDCl}_{3}\right): \delta 7.33-7.05(\mathrm{~m}, 6 \mathrm{H})$ 7.04-6.91 (m, $1 \mathrm{H}), 6.70(\mathrm{~d}, J=8.5 \mathrm{~Hz}, 1 \mathrm{H}), 6.13-5.91(\mathrm{~m}, 2 \mathrm{H}), 5.46(\mathrm{~d}, J=$ $8.5 \mathrm{~Hz}, 1 \mathrm{H}), 5.36-5.10(\mathrm{~m}, 2 \mathrm{H}), 4.87-4.71(\mathrm{~m}, 1 \mathrm{H}), 4.67-4.43(\mathrm{~m}$, $1 \mathrm{H}), 4.38-4.23(\mathrm{~m}, 2 \mathrm{H}), 4.23-3.69(\mathrm{~m}, 4 \mathrm{H}), 3.69-3.41(\mathrm{~m}, 1 \mathrm{H})$, $3.21(\mathrm{dd}, J=14.3, J=5.0 \mathrm{~Hz}, 1 \mathrm{H}), 3.10-2.79(\mathrm{~m}, 2 \mathrm{H}), 2.54(\mathrm{dd}$, $J=14.3, J=5.0 \mathrm{~Hz}, 1 \mathrm{H}), 2.30-1.99(\mathrm{~m}, 1 \mathrm{H}), 1.89-1.55(\mathrm{~m}, 3 \mathrm{H})$, $1.49(\mathrm{~m}, 9 \mathrm{H}), 1.31(\mathrm{~m}, 12 \mathrm{H}) \mathrm{ppm}$.

${ }^{13} \mathrm{C} \mathrm{NMR}\left(75 \mathrm{MHz}, \mathrm{CDCl}_{3}\right): \delta 173.14,172.90,171.92,171.23$, $170.66,170.49,159.68,158.86,155.92,155.18,153.77 .153 .59$, $136.00,129.63,129.43,129.15,128.60,128.41,127.14,127.05$, $86.96,85.53,79.99,79.88,58.23,57.68,54.13,53.47,52.97,52.19$, $51.05,48.82$, 41.04, 40.85, 39.32, 30.88, 30.66, 28.45, 28.30, 25.05, 24.81, 22.91, 22.01, 21.51, 19.28, 17.98, 17.84 ppm.

HRMS (ESI) $[\mathrm{M}+\mathrm{Na}]^{+}$calculated for $\mathrm{C}_{31} \mathrm{H}_{46} \mathrm{~N}_{6} \mathrm{O}_{7} \mathrm{Na}$ : 637.3326, found: 637.3332 .

\section{NH-Boc-Phe-Gly-(+)- $\Delta^{2}$-isox-Leu-Val-CONH 2 (10)}

${ }^{1} \mathrm{H}$ NMR (300 MHz, $\left.\mathrm{CD}_{3} \mathrm{CN}\right): \delta 7.47(\mathrm{~d}, J=6.9 \mathrm{~Hz}, 1 \mathrm{H}), 7.30-$ $7.26(\mathrm{~m}, 6 \mathrm{H}), 6.95(\mathrm{~d}, J=8.5 \mathrm{~Hz}, 1 \mathrm{H}), 6.72$ (bs, $1 \mathrm{H}), 6.42$ (bs, $1 \mathrm{H})$, 5.63 (bs, $1 \mathrm{H}), 5.47-5.31(\mathrm{~m}, 1 \mathrm{H}), 4.52-4.47(\mathrm{~m}, 1 \mathrm{H}), 4.40-3.39$ (m, 8H), 3.23-3.07 (m, 1H), 2.70-2.93 (m, 1H), 2.14-2.08 (m, $1 \mathrm{H}), 1.78-1.55(\mathrm{~m}, 3 \mathrm{H}), 1.35(\mathrm{~s}, 9 \mathrm{H}), 1.02-0.77(\mathrm{~m}, 12 \mathrm{H}) \mathrm{ppm}$.

${ }^{13} \mathrm{C}$ NMR $\left(75 \mathrm{MHz}, \mathrm{CD}_{3} \mathrm{CN}\right): \delta 173.43,171.63,167.09,159.52$, $154.34,137.64,129.27,128.31,126.53,109.99,87.41,86.02,79.09$, 
58.06, 56.82, 55.76, 53.67, 52.65, 51.39, 49.79, 48.71, 41.62, 40.43, $40.10,37.60,31.51,30.55,29.34,27.49,24.77,22.27,20.81,18.86$, 17.21, $16.63 \mathrm{ppm}$.

HRMS (ESI) $[\mathrm{M}+\mathrm{Na}]^{+}$calculated for $\mathrm{C}_{33} \mathrm{H}_{49} \mathrm{~N}_{7} \mathrm{O}_{8} \mathrm{Na}$ : 694.3540, found: 694.3539 .

\section{General Procedure for $\boldsymbol{N}$-Boc-Deprotection}

$N$-Boc protected compound (1 equiv.) was dissolved in $\mathrm{CH}_{2} \mathrm{Cl}_{2}$ $(0.01 \mathrm{M})$ and the solution cooled at $0^{\circ} \mathrm{C}$. TFA $(50 \% \mathrm{v} / \mathrm{v})$ was added dropwise, the solution was warmed up at room temperature and was stirred for $2 \mathrm{~h}$. The solvent was removed under vacuum with the obtainment of the trifluoroacetate salt that was directly used in the next coupling step.

\begin{tabular}{lc}
\hline Product & Yield (\%) \\
\hline $\mathbf{3}^{\mathrm{a}}$ & 95 \\
$\mathbf{6}$ & 95 \\
$\mathbf{7}$ & 95 \\
\hline
\end{tabular}

a see Smith and Spackman (1955).

\section{NH-(-)- $\Delta^{2}$-isox-Leu-Val-CONH2 (6)}

${ }^{1} \mathrm{H}$ NMR (300 MHz, CD 3 OD): $\delta 7.90(\mathrm{~d}, J=8.7 \mathrm{~Hz}, 1 \mathrm{H}), 5.53$ $(\mathrm{dd}, J=9.5,4.9 \mathrm{~Hz}, 1 \mathrm{H}), 4.54(\mathrm{dd}, J=9.8,4.9 \mathrm{~Hz}, 1 \mathrm{H}), 4.42(\mathrm{t}, J$ $=8.8 \mathrm{~Hz}, 1 \mathrm{H}), 4.26-4.17(\mathrm{~m}, 1 \mathrm{H}), 3.90-3.84(\mathrm{~m}, 1 \mathrm{H}), 3.89-$ $3.75(\mathrm{~m}, 2 \mathrm{H}), 3.58-3.49(\mathrm{~m}, 2 \mathrm{H}), 3.22(\mathrm{dd}, J=5.9,4.1 \mathrm{~Hz}, 1 \mathrm{H})$, $2.05(\mathrm{dq}, J=13.6,6.8 \mathrm{~Hz}, 1 \mathrm{H}), 1.80-1.59(\mathrm{~m}, 3 \mathrm{H}), 1.05-0.82$ (m, 12H) ppm.

${ }^{13} \mathrm{C}$ NMR (75 MHz, $\left.\mathrm{CD}_{3} \mathrm{OD}\right): \delta 147.47,172.82,159.52,152.51$, $85.48,58.22,52.96,52.21,50.55,49.27,40.31,30.68,24.54,21.98$, 20.47, 18.32, $17.08 \mathrm{ppm}$.

HRMS (ESI) $[\mathrm{M}+\mathrm{Na}]^{+}$calculated for $\mathrm{C}_{17} \mathrm{H}_{29} \mathrm{~N}_{5} \mathrm{O}_{4} \mathrm{Na}$ : 390.2117, found: 390.2111 .

\section{$\mathrm{NH}$-(+)- $\Delta^{2}$-isox-Leu-Val-CONH2 (7)}

${ }^{1} \mathrm{H}$ NMR (300 MHz, CD $\left.{ }_{3} \mathrm{OD}\right) ; \delta 7.97(\mathrm{~d}, J=8.6 \mathrm{~Hz}, 1 \mathrm{H}), 5.53$ $(\mathrm{dd}, J=9.5,4.9 \mathrm{~Hz}, 1 \mathrm{H}), 4.55(\mathrm{~m}, 1 \mathrm{H}), 4.39(\mathrm{~m}, 1 \mathrm{H}), 4.26-4.16$ $(\mathrm{m}, 1 \mathrm{H}), 3.90-3.72(\mathrm{~m}, 2 \mathrm{H}), 3.58-3.43(\mathrm{~m}, 2 \mathrm{H}), 3.24-3.16(\mathrm{~m}$, $1 \mathrm{H}), 2.05(\mathrm{~m}, 1 \mathrm{H}), 1.75-1.58(\mathrm{~m}, 3 \mathrm{H}), 1.02-0.81(\mathrm{~m}, 12 \mathrm{H}) \mathrm{ppm}$.

${ }^{13} \mathrm{C} \mathrm{NMR}\left(75 \mathrm{MHz}, \mathrm{CD}_{3} \mathrm{OD}\right): \delta 147.47,172.99,159.40,152.40$, 128.72, 85.21, 58.05, 53.12, 52.17, 50.66, 49.14, 40.21, 30.91, 29.36, $24.84,21.99,20.25,18.26,16.90 \mathrm{ppm}$.

HRMS (ESI) $[\mathrm{M}+\mathrm{Na}]^{+}$calculated for $\mathrm{C}_{17} \mathrm{H}_{29} \mathrm{~N}_{5} \mathrm{O}_{4} \mathrm{Na}$ : 390.2117, found: 390.2111 .

\section{Molecular Modeling}

Compound $\mathbf{9}$ and $\mathbf{1 0}$ were modeled in explicit solvent with periodic boundary conditions using metadynamics and restrained molecular dynamics simulations. For each of the compounds two isomers (cis and trans with respect to the amide bond) were considered, resulting in a set of four peptides. Such molecules were solvated in a cubic box of $4 \mathrm{~nm}$ with chloroform (compound 8) and acetonitrile (compound 10) to reproduce the NMR experiment conditions. Every system has been submitted to geometry optimization with the steepest descent algorithm with a convergence of $100 \mathrm{~kJ} \mathrm{~mol}^{-1} \mathrm{~nm}^{-1}$. Then we performed a 1 ns equilibration in NVT conditions at $300 \mathrm{~K}$, followed by a 1 ns NPT equilibration at the 1 bar and at the same temperature. After the equilibration phase, we ran a $50 \mathrm{~ns}$ Well Tempered Metadynamics (WTMD) with a $8.0 \mathrm{~kJ} \mathrm{~mol}^{-1}$ bias-factor, at a reference temperature of $300 \mathrm{~K}$. To study the open and closed state of both peptides, we selected as collective variable (CV) the distance between $\mathrm{C}_{\beta} \mathrm{VAL}$ and the $N$-tert-butoxy carbonyl (N-Boc) quaternary carbon. A Gaussian hill with $\sigma=0.1 \AA$ and an initial height of $1 \mathrm{~kJ} \mathrm{~mol}^{-1}$ was added once every 100 steps. The simulation was sped up by saving the Gaussian hills on a grid that ranged from 0 to $16 \AA$ and spaced $0.02 \AA$. Compound 10 was also simulated using a 50 ns restrained molecular dynamics. Special potentials are used for imposing restraints on the motion of the system, to include knowledge from experimental data such as the NMR derived interatomic distances. Distance restraints add a penalty to the potential when the distance between specified pairs of atoms exceeds a threshold value (Abraham et al., 2014). The threshold values used in our simulation are reported in the Supplementary Materials.

The restraints are applied in a progressive way to give time to the peptide to relax, using a $\tau$ equal to $500 \mathrm{ps}$. Since we are using multiple distance restraints, they are not necessary satisfied at each simulation step but as a time average. The atoms restrained and the relative distances are shown in Table S1. Compound $\mathbf{9}$ and $\mathbf{1 0}$ have been described using the Amber99SB-ILDN Force Field (Hornak et al., 2006). 4,5,6,6a-Tetrahydro-3aH-pyrrolo[3,4-d]isoxazole3 -carboxylic acid residues were parameterized according to standard procedures as explained in reference (Gandini et al., 2018). During molecular dynamics (MD) and metadynamics simulations, temperature was held constant with the v-rescale algorithm (Bussi et al., 2007), while pressure was kept constant through the Berendsen barostat (Berendsen et al., 1984). MD simulations were performed using the leap-frog algorithm with 2 fs time-step, with holonomic constraints on every bond enforced using the LINCS algorithm. Simulations and subsequent analysis were performed with the GROMACS 5.0.4 (Van Der Spoel et al., 2005) program suite, while metadynamics was run along with PLUMED version 2.2.2 (Tribello et al., 2014).

\section{RESULTS AND DISCUSSION}

The two enantiomers of compound $\mathbf{1}$ were obtained starting from the corresponding ethyl esters recently described by us (Tamborini et al., 2015). Racemate ( \pm )-2 (Conti et al., 2006) was synthesized in a flow chemistry reactor exploiting the 1,3-dipolar cycloaddition reaction of $N$ Boc-3-pyrroline with ethoxycarbonyl formonitrile oxide. An excellent enantiomeric separation (e.e. $>99 \%$ ) of the racemate was achieved by semi-preparative chiral HPLC. Alkaline hydrolysis of (-)-(3aS6aR)-2 and (+)-(3aR6aS)2 gave the desired (-)-(3aS6aR)-1 and (+)-(3aR6aS)-1, respectively (Scheme 1).

The ability of compound $\mathbf{1}$ to stabilize secondary structures was evaluated in model peptides containing (L)-Phe at $N$-terminus and (L)-Leu-(L)-Val sequence at $C$-terminus and (Schemes 2, 3). This last dipeptide was chosen as it normally adopts extended conformation in solution. Compound 1 was used in both the $3 \mathrm{aS} 6 \mathrm{a} R$ and $3 \mathrm{aR} 6 \mathrm{a} S$ 
stereochemistries [(-)-1 and (+)-1, respectively], as a different effect on peptide conformations could be expected depending on the stereochemistry of the unnatural amino acids (Pellegrino et al., 2012).

Firstly, Leu-Val dipeptide 3 was prepared starting from (L)-Valinamide and $\mathrm{NH}$-Boc-(L)-Leu, according to the general coupling procedure, followed by $\mathrm{N}$-terminus deprotection in TFA (91\% overall yield). Diastereoisomeric dipeptides 4 and 5 were then achieved in good yields $(65 \%$ and $63 \%$, respectively) by a coupling reaction of (-)-1 or (+)-1 with dipeptide 3 (Scheme 2).

Both 4 and 5 compounds were completely characterized by $\mathrm{NMR}$ spectroscopy $\left(\mathrm{CDCl}_{3}\right.$, see SI for complete proton assignment). In both tripeptides, no significant Noesy effects between Leu-Val dipeptide and the scaffold were detected. Furthermore, in variable temperature experiments, the obtained $\Delta \delta / \Delta \mathrm{T}$ is higher than $5 \mathrm{ppb} / \mathrm{K}$ for all the amide protons, indicating the absence of $\mathrm{H}$-bonds stabilizing a particular

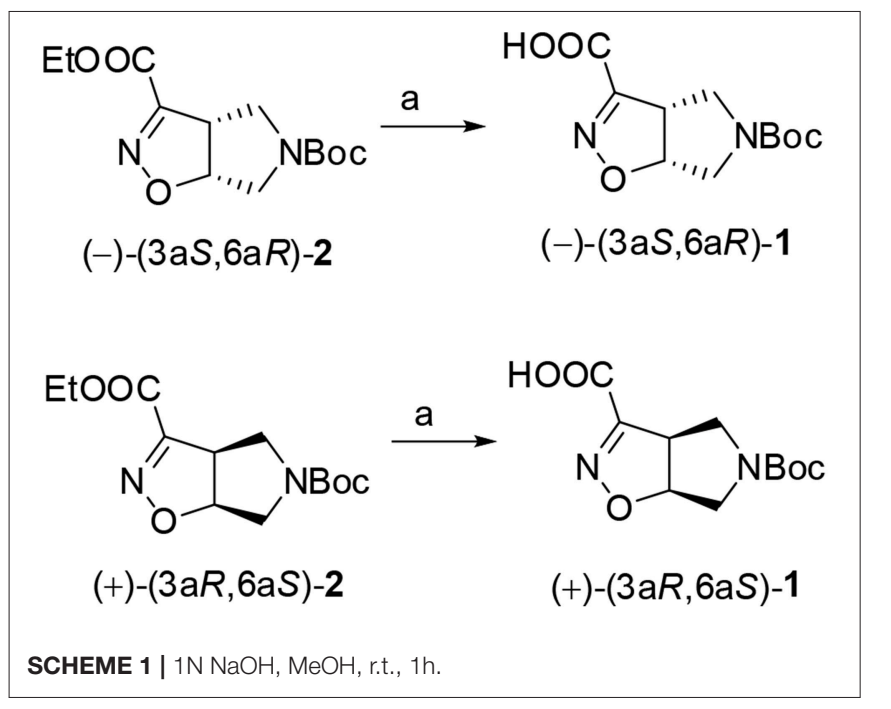

conformation. The $J_{\mathrm{NH}-\mathrm{CH} \alpha}$ value for $\mathrm{NH}-\mathrm{Val}$ is of $8.8 \mathrm{~Hz}$ and $7.9 \mathrm{~Hz}$, for 4 and $\mathbf{5}$, respectively ( $\mathrm{NH}$-Leu appears as a broad signal for each compound). From these findings, we hypothesized that both $\mathbf{4}$ and $\mathbf{5}$ adopt an extended conformation and that the isoxazoline scaffold is not interacting with LeuVal dipeptide.

The peptide chain was then elongated at $N$-terminus, through Boc-deprotection and coupling with (L)-Phe. Diastereoisomeric dipeptides 8 and $\mathbf{9}$ were achieved in good overall yields $(73 \%$ and $76 \%$, respectively) (Scheme 3). From NMR studies, it was found that both model peptides $\mathbf{8}$ and $\mathbf{9}$ are present as a mixture of conformers in 2:1 ratio in $\mathrm{CDCl}_{3}$ solution. The presence of these two conformers is probably due to the low-energy barrier cis/trans isomerization of the tertiary amide on the pyrrolidine as it is frequently observed on the acylated proline and in the case of tertiary cyclic amides (Laursen et al., 2013; Pellegrino et al., 2014). Regarding compound $\mathbf{8}$, this rotation led to a splitting of the (L)-Phe proton signals only. Furthermore, no significative Noesy effects were detected, and, in variable temperature experiments, the obtained $\Delta \delta / \Delta \mathrm{T}$ coefficient is high for all the amide protons. Taking all these data together, we can assume that Phe and LeuVal dipeptide are oriented in opposite directions and that the $3 \mathrm{aS} 6 \mathrm{a} R$ stereochemistry of the scaffold is not effective in inducing specific secondary structures when used in combination with (L)- $\alpha$-amino acids.

A different scenario was observed for compound 9. Its two rotamers are indeed characterized by different chemical shifts, suggesting that the isomerization of the tertiary amide leads to two different structures conformations influencing the entire molecule. Unfortunately, due to several overlapping signals, it was not possible to assessing significative Noesy proximities. Variable temperature experiments were thus done, in order to investigate if the $\mathrm{NH}$ were involved in hydrogen bonds and, as a consequence, if the two isomers of $\mathbf{9}$ were characterized by a stable conformation in solution. In the case of the major isomer, the obtained $\Delta \delta / \Delta \mathrm{T}$ is around $4 \mathrm{ppb} / \mathrm{K}$ for $\mathrm{NH}$-Phe, indicating that this proton could be involved in a weak/medium hydrogen bond. All the other amide protons had higher $\Delta \delta / \Delta T$. On the

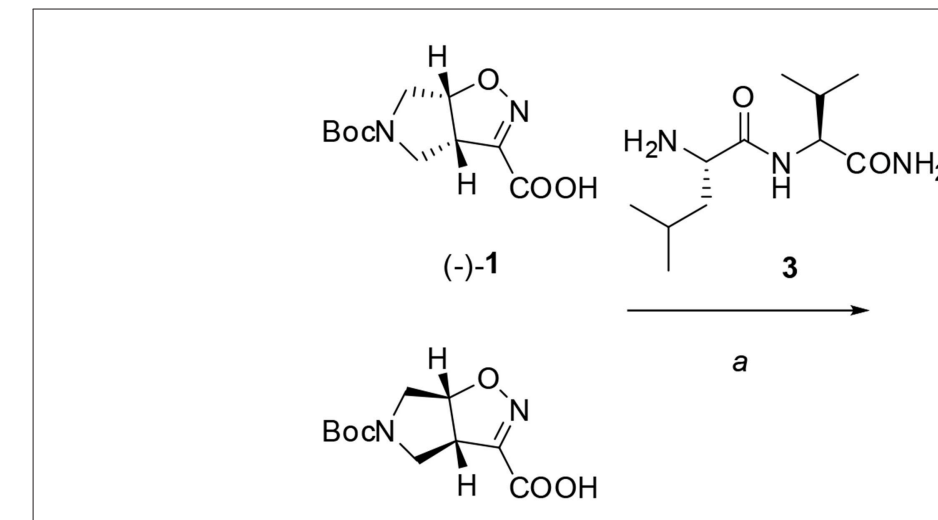

(+)-1<smiles>CC(C)C[C@H](NC(=O)C1=NO[C@@H]2CN(C(C)(C)C)C[C@H]12)C(=O)NC(C(N)=O)C(C)C</smiles><smiles>CC(C)C[C@H](NC(=O)C1=NO[C@@H]2CN(C(=O)OC(C)(C)C)C[C@H]12)C(=O)NC(C(N)=O)C(C)C</smiles>

SCHEME 2 | Reagents and conditions: a) EDC/HOBt/DIEA, $\mathrm{CH}_{2} \mathrm{Cl}_{2}$ from $0^{\circ} \mathrm{C}$ to r.t., 24 h. 


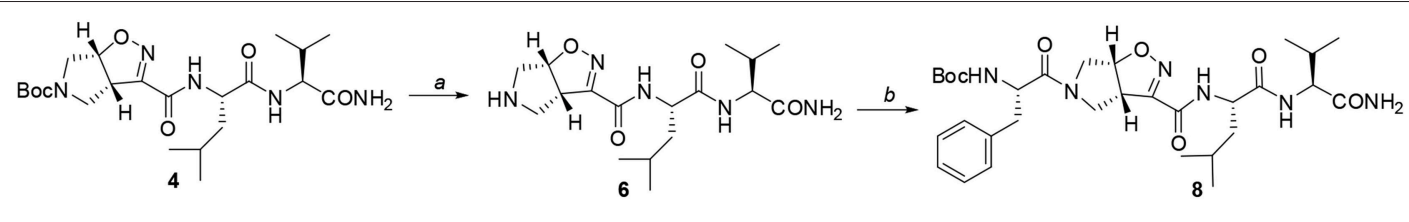

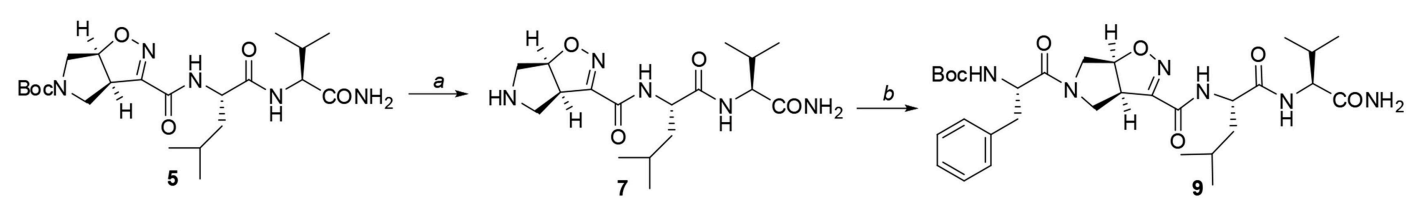<smiles>CC(C)CC(NC(=O)C1=NO[C@@H]2CN(C(=O)CNC(=O)C(Cc3ccccc3)NC(=O)OCc3ccccc3)C[C@H]12)C(N)=O</smiles>

SCHEME 3 | Reagents and conditions: a) TFA, $\mathrm{CH}_{2} \mathrm{Cl}_{2}$ from $0^{\circ} \mathrm{C}$ to r.t, $2 \mathrm{~h}$; b) EDC/HOBt/DIEA, N-Boc-(L)-Phe, $\mathrm{CH}_{2} \mathrm{Cl}_{2}$ from $0^{\circ} \mathrm{C}$ to r.t, $24 \mathrm{~h}$; c) EDC/HOBt/DIEA, $\mathrm{N}$-Boc-(L)-Phe-Gly-OH, $\mathrm{CH}_{2} \mathrm{Cl}_{2}$ from $0^{\circ} \mathrm{C}$ to r.t, $24 \mathrm{~h}$.

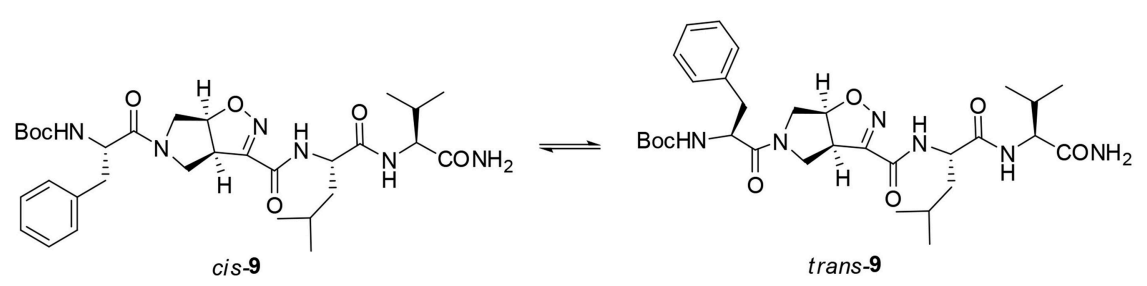

FIGURE 2 | Cis and trans isomers of compound $\mathbf{9}$

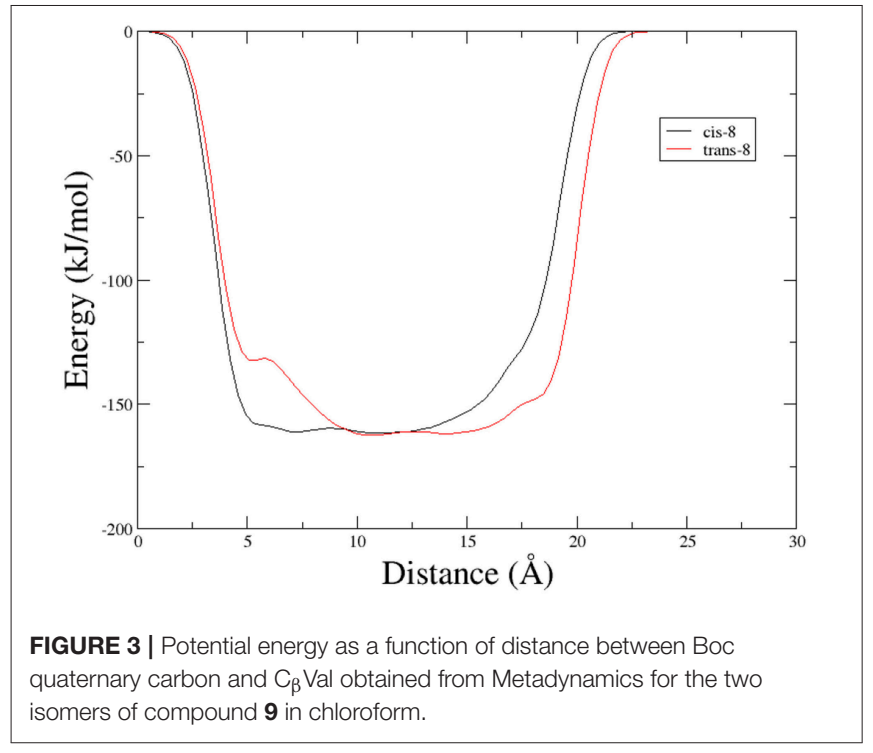

other hand, in the minor conformer the obtained $\Delta \delta / \Delta \mathrm{T}$ is of around $2 \mathrm{ppb} / \mathrm{K}$ for $\mathrm{NH}-\mathrm{Val}$, indicating that this proton is involved in a strong hydrogen bond. Metadynamic studies were then performed on the cis/trans tertiary amide conformers of compound 9 (Figure 2).

In particular, we performed two 50 ns long metadynamics simulations, using the distance between Boc quaternary carbon and $\mathrm{C}_{\beta} \mathrm{Val}$ as collective variable $(\mathrm{CV})$. This geometric parameter was selected as a suitable $\mathrm{CV}$ because it discriminates well between closed and extended states of the peptide. In this way, it could be possible to evaluate if the two conformers had an intrinsic tendency toward turn conformation. The cis isomer showed a broad free energy minimum corresponding to $\mathrm{CV}$ values between 5 and $8 \AA$, while the trans isomer showed much higher free energy values in this region, exhibiting a shallow minimum around 10-15 (Figure 3).

This different behavior could be indicative of a preference of cis-9 toward a more closed conformation, although from these data it was not possible to make any further assumptions. For this reason, we envisaged that the introduction of a Gly residue between Phe and isoxazoline scaffold could increase the conformational flexibility of the $N$-terminus peptide arm favoring its interaction with the $C$-teminus part of the molecule. Compound 7 was thus elongated at $N$-terminus, through coupling with $\mathrm{N}$-Boc-(L)-Phe-Gly-OH dipeptide using general coupling reaction conditions to obtain peptide $\mathbf{1 0}$ 

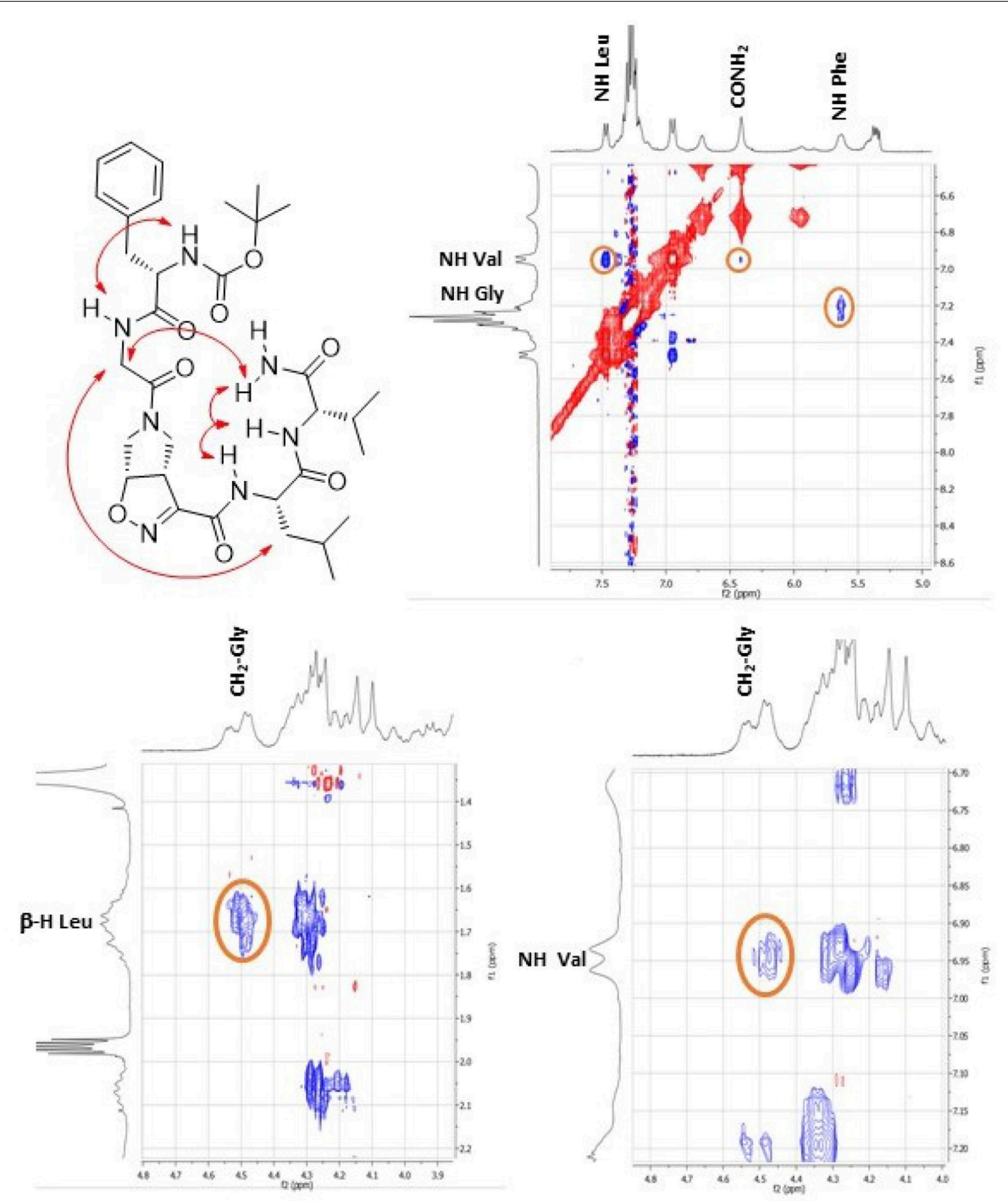

FIGURE 4 | Noesy proximity (red) observed for compound $\mathbf{1 0}\left(\mathrm{CD}_{3} \mathrm{CN}\right)$. On the top right: zoom of the amide region. On the bottom left: Zoom of the aliphatic region. On the bottom right: zoom of the $\mathrm{NH}$-aliphatic region.

(65\%, Scheme 3). The NMR study on $10\left(\mathrm{CD}_{3} \mathrm{CN}\right.$, see SI for complete assignment), showed that it is present in solution as a single stable conformer (only trace amounts of a second isomer were detected). A complete set of $\mathrm{NH}_{\mathrm{i}}-\mathrm{NH}_{\mathrm{i}+1}$ Noesy proximities, whose calculated distances ranged from 2.68 to $2.96 \AA$, were observed (Figure 4 on the top right). Furthermore, long range Noesy effects involving $\mathrm{H} \alpha \mathrm{Gly}$ and NHVal $(3.03 \AA$ ) and H $\beta$ Leu (2.73 $\AA$ ) were found (Figure 4 on the bottom).

In variable temperature experiments (Figure 5), the obtained $\Delta \delta / \Delta \mathrm{T}$ is of around $2 \mathrm{ppb} / \mathrm{K}$ for $\mathrm{NH}-\mathrm{Val}$, while $\mathrm{NH}-\mathrm{Leu}$ and one of the C-terminus amide protons possess $\Delta \delta / \Delta \mathrm{T}$ of around 3 and $4 \mathrm{ppb} / \mathrm{K}$, respectively. The presence of hydrogen bonds was also confirmed by FT-IR analysis. N-H stretching bands $A$ and $B\left(3,500-3,000 \mathrm{~cm}^{-1}\right.$ region, Figure S20) are indeed downshifted as frequently observed in intramolecular hydrogen bonded conformations (Tonan and Ikawa, 1996; Barth, 2007). Furthermore, the deconvolution of the amide I band (1,700$1,600 \mathrm{~cm}^{-1}$ ) showed the presence of a band at $1,655 \mathrm{~cm}^{-1}$ (Figure S20), typical of $\alpha$ structures (Kong and $\mathrm{Yu}, 2007$ ).

In order to gain more information on the conformation of compound 10, far-UV circular dichroism (CD) analysis in $\mathrm{CH}_{3} \mathrm{CN}$ (0.1 mM solution) was then performed. In Figure 6 the obtained CD spectrum is reported.

It showed a maximum at around $250 \mathrm{~nm}$ due to the strong absorption of the isoxazoline ring, as observed by Memeo et al. (2018) on similar compounds (see also the UV spectrum in the SI). In the amide bond region, two negative minima at 225 and $208 \mathrm{~nm}$, with the same intensity, and a slightly positive band at $200 \mathrm{~nm}$ were also observed. The presence of the exciton splitting of the $\pi \rightarrow \pi^{*}$ transition band suggested that a $\alpha$-turn conformation was present (Wang et al., 2018), although in short 


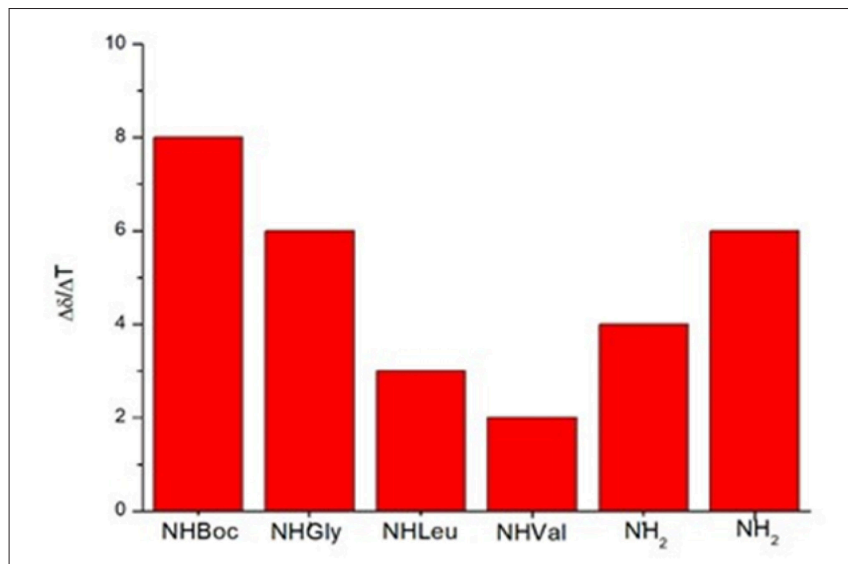

FIGURE 5 | Variable temperature coefficients of the amide protons $\left(\mathrm{CD}_{3} \mathrm{CN}\right)$.

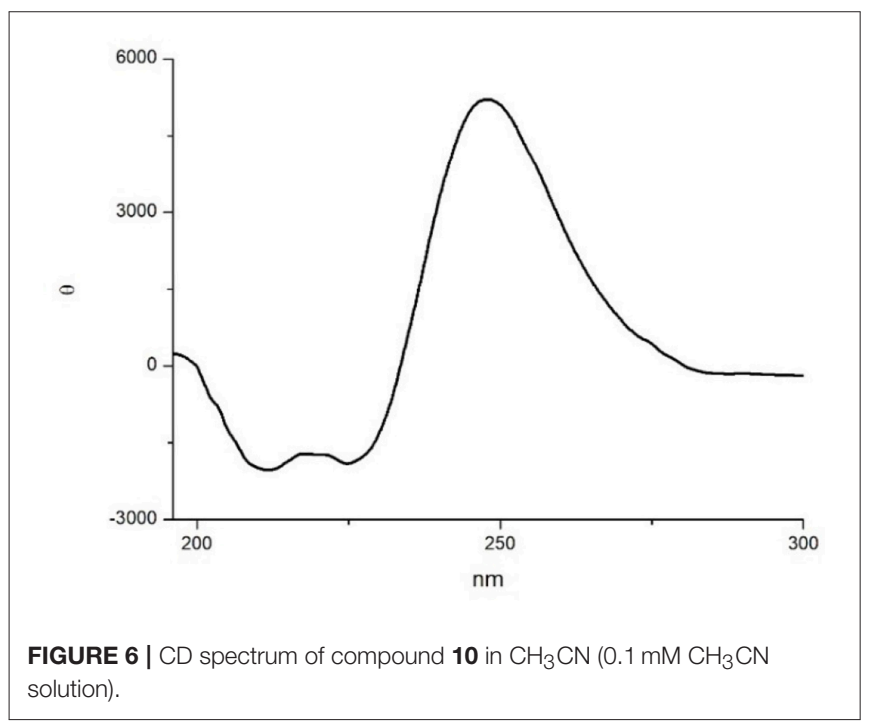

peptides it is difficult to correctly evaluate the intensity of Cotton effects with respect to secondary structure motifs (Chin et al., 2002; Wang et al., 2018).

In order to completely elucidate the conformation of peptide 10, a restrained molecular dynamic was finally performed. The restraints were based on the obtained NOESY values. When the hydrogen was not uniquely defined, like in $\mathrm{H}_{\alpha}$ Gly and $\mathrm{H}_{\beta}$ Leu, we used the closest carbon, e.g., $\mathrm{C}_{\alpha}$ Gly and $\mathrm{C}_{\beta}$ Leu to implement distance restrains (Figure S3). The analysis showed that $\mathrm{C}_{\alpha}$ Gly- $\mathrm{C}_{\beta}$ Leu (A) and $\mathrm{C}_{\alpha}$ Gly- $\mathrm{H}_{\mathrm{NH}}$ Val (B) are mutually exclusive in the trans isomer but not in the cis one as shown in Figure S1. Furthermore, H-bond analysis resulted in the observation that a $\mathrm{H}$-bond is between $\mathrm{CO}$ Gly and NH-Val. In Figure 7 the most representative structure is reported.

Taking together both experimental and molecular modeling data, we can assume that, in solution, compound $\mathbf{1 0}$ effectively adopts a $\alpha$-turn conformation. This motif is normally formed

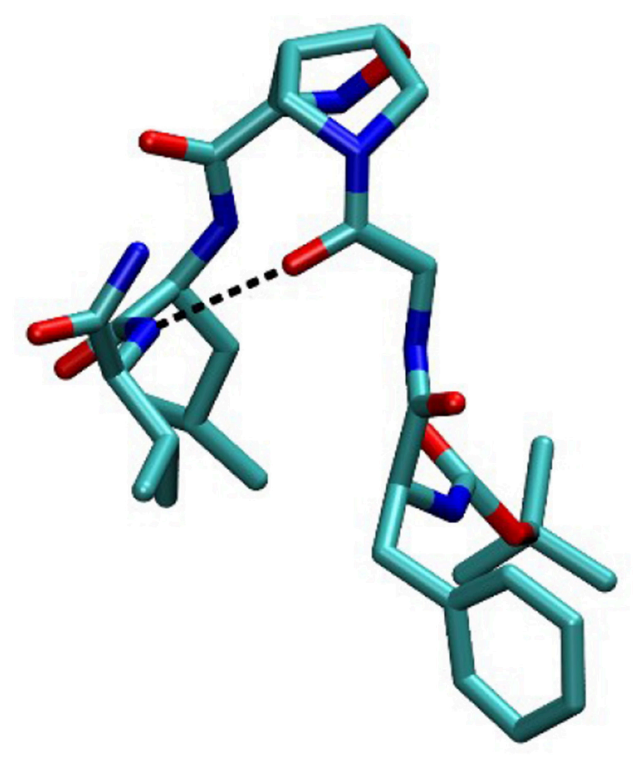

FIGURE 7 | Compound $\mathbf{1 0}$ conformation during the restained MD.

by $5 \alpha$-amino acids and is characterized by a $\mathrm{H}$-bond between $i$ and $i+4$ residues. In our case, the isoxazoline scaffold replaces two of the three core amino acids (Figure 1) and the H-bond is formed by the CO-Gly and NH-Val, leading to the formation of a 12 member pseudo-cycle. Furthermore, the overall structure of the peptidomimetic is reinforced by medium-weak H-bonds involving $\mathrm{NH}$-Leu and one C-terminus- $\mathrm{NH}_{2}$, as evicted from NMR data. The presence of a $\alpha$-turn conformation is also confirmed by the computational analysis of the dihedral angles of the residue $i+3$ and of the distances between residues $i$ and $\mathrm{i}+4$ (Table S9), as their values rely within the $\alpha$-turn parameters (Pavone et al., 1996).

In conclusion, as $\alpha$-turns are often found on biologically active sites and few molecules have been reported to mimic or stabilize them, the ability of compound $(+)-1$ to stabilize $\alpha$-turn conformation on isolated peptide is particularly important in view of future biological applications.

\section{DATA AVAILABILITY}

All datasets generated for this study are included in the manuscript and/or the supplementary files.

\section{AUTHOR CONTRIBUTIONS}

FO and RB equally contributed to this work. The project was conceived by SaP, LT, and AP. SaP designed and coordinated the research. LT and $\mathrm{RB}$ chemically synthesized and analyzed the materials, RB performed NMR, FT-IR and CD experiments, FO and StP performed molecular modeling. SaP, StP, LT, and AP analyzed and compiled the data and co-wrote the manuscript. The final manuscript was read and approved by all the authors. 


\section{ACKNOWLEDGMENTS}

We thank Donatella Nava for the NMR analysis and Michele Consonni and Sabrina Giofrè for practical help in the synthesis.

\section{REFERENCES}

Abraham, M., Van Der Spoel, D., Lindahl, E., and Hess, B. (2014). GROMACS User Manual Version 5.0.4. Available online at: https://ftp.gromacs.org/pub/manual/ manual-5.0.4.pdf

Barth, A. (2007). Infrared spectroscopy of proteins. BBA Bioenerg. 1767, 1073-1101. doi: 10.1016/j.bbabio.2007.06.004

Berendsen, H. J. C., Postma, J. P. M., van Gusteren, W. F., and DiNola, A. (1984). Molecular dynamics with coupling to an external bath. J. Chem. Phys. 81, 3684-3690. doi: 10.1063/1.448118

Bonetti, A., Pellegrino, S., Das, P., Yuran, S., Bucci, R. Ferri, N., et al. (2015). Dipeptide Nanotubes Containing Unnatural Fluorine-Substituted $\beta 2,3-$ Diarylamino Acid and l-Alanine as candidates for biomedical applications. Org. Lett. 17, 4468-4471. doi: 10.1021/acs.orglett.5b02132

Bouillère, F., Thétiot-Laurent, S., Kouklovsky, C., and Alezra, V. (2011). Foldamers containing $\gamma$-amino acid residues or their analogues: structural features and applications. Amino Acids 41, 687-707. doi: 10.1007/ s00726-011-0893-3

Bruno, S., Pinto, A., Paredi, G., Tamborini, L., De Micheli, C., La Pietra, V., et al. (2014). Discovery of covalent inhibitors of glyceraldehyde-3-phosphate dehydrogenase, a target for the treatment of malaria. J. Med. Chem. 57, 7465-7471. doi: 10.1021/jm500747h

Bucci, R., Das, P., Iannuzzi, F., Feligioni, M., Gandolfi, R., Gelmi, M. L., et al. (2017). Self-assembly of an amphipathic $\alpha \alpha \beta$-tripeptide into cationic spherical particles for intracellular delivery. Org. Biomol, Chem. 15, 6773-6779. doi: 10.1039/C7OB01693J

Bucci, R., Giofré, S., Clerici, F., Contini, A., Pinto, A., Erba, E., et al. (2018). Tetrahydro-4H-(pyrrolo[3,4- $d$ ] isoxazol-3-yl)methanamine: a bicyclic diamino scaffold stabilizing parallel turn conformations. J. Org. Chem. 83, 11493-11501. doi: $10.1021 /$ acs.joc.8b01299

Bussi, G., Donadio, D., and Parrinello, M. (2007). Canonical sampling through velocity rescaling. J. Phys Chem. 126:014101. doi: 10.1063/ 1.2408420

Castellano, S., Kuck, D., Viviano, M., Yoo, J., López-Vallejo, F., Conti, P., et al. (2011). Synthesis and biochemical evaluation of $\delta 2$-isoxazoline derivatives as DNA methyltransferase 1 inhibitors. J. Med. Chem. 54, 7663-7677. doi: $10.1021 / \mathrm{jm} 2010404$

Chatterjee, S., Vasudev, P. G., Raghothama, S., Ramakrishnan, C., Shamala, N., and Balaram, P. (2009). Expanding the peptide $\beta$-turn in $\alpha \gamma$ hybrid sequences: 12 atom hydrogen bonded helical and hairpin turns. J. Am. Chem. Soc. 131, 5956-5965. doi: 10.1021/ja900618h

Chin, D.-H., Woody, R. W., Rohl, C. A., and Baldwin, R. L. (2002). Circular dichroism spectra of short, fixed-nucleus alanine helices. Proc. Natl. Acad. Sci. U.S.A. 99, 15416-15421. doi: 10.1073/pnas.232591399

Clerici, F., Erba, E., Gelmi, M. L., and Pellegrino, S. (2016). Non-standard amino acids and peptides: from self-assembly to nanomaterials Tetrahedron Lett. 57, 5540-5550. doi: 10.1016/j.tetlet.2016.11.022

Conti, P., De Amici, M., Pinto, A., Tamborini, L., Grazioso, G., Frolund, B., et al. (2006). Synthesis of 3-hydroxy- and 3-carboxy- $\Delta 2$-isoxazoline amino acids and evaluation of their interaction with GABA receptors and transporters. Eur. J. Org. Chem. 24, 5533-5542. doi: 10.1002/ejoc.200600628

Conti, P., Pinto, A., Wong, P. E., Major, L. L., Tamborini, L., Iannuzzi, M. C., et al. (2011). Synthesis and in vitro/in vivo evaluation of the antitrypanosomal activity of 3-bromoacivicin, a potent CTP synthetase inhibitor. ChemMedChem 6, 329-333. doi: 10.1002/cmdc.201000417

Fanelli, R., Berthomieu, D., Didierjean, C., Doudouh, A., Lebrun, A., Martinez, J., et al. (2017). Hydrophobic $\alpha, \alpha$-disubstituted disilylated TESDpg induces incipient 310-Helix in short tripeptide sequence. Org. Lett. 19, 2937-2940. doi: 10.1021 /acs.orglett.7b01172

\section{SUPPLEMENTARY MATERIAL}

The Supplementary Material for this article can be found online at: https://www.frontiersin.org/articles/10.3389/fchem. 2019.00133/full\#supplementary-material

Fuller, A., Chen, B., Minter, A. R., and Mapp, A. K. (2005). Succinct synthesis of $\beta$-amino acids via chiral isoxazolines. J. Am. Chem. Soc. 127, 5376-5383. doi: $10.1021 /$ ja0431713

Gandini, E., Dapiaggi, F., Oliva, F., Pieraccini, S., and Sironi, M. (2018) Well-Tempered MetaDynamics based method to evaluate universal peptidomimetics. Chem. Phys. Lett. 706, 729-735. doi: 10.1016/j.cplett.2018.07.029

Guo, L., Zhang, W., Guzei, I. A., Spencer, L. C., and Gellman, S. H. (2012). New preorganized $\gamma$-amino acids as foldamer building blocks. Org. Lett. 14, 2582-2585. doi: 10.1021/ol3008815

Hoang, H. N., Driver, R. W., Beyer, R. L., Malde, A. K., Le, G. T., Abbenante G., et al (2011). Protein $\alpha$-turns recreated in structurally stable small molecules. Angew Chem. Int. Ed. 50, 11107-11111. doi: 10.1002/anie.201105119

Hornak, V., Abel, R., Okur, A., Strockbine, B., Roitberg, A., and Simmerling, C. (2006). Comparison of multiple Amber force fields and development of improved protein backbone parameters. Proteins 65, 712-725. doi: $10.1002 /$ prot. 21123

Itoh, T., Watanabe, M., and Fukuyama, T. (2002). Synthetic approach to tetrodotoxin. Synlett 8, 1323-1325. doi: 10.1055/s-2002-32984

Kaur, K., Kumar, V., Sharma, A. K., and Gupta, G. K. (2014). Isoxazoline containing natural products as anticancer agents: a review. Eur. J. Med. Chem. 77, 121-133. doi: 10.1016/j.ejmech.2014.02.063

Kelso, M. J., Beyer, R. L., Hoang, H. N., Lakdawala, A. S., Snyder, J. P., Oliver, W. V., et al. (2004). Alpha-turn mimetics: short peptide alpha-helices composed of cyclic metallopentapeptide modules. J Am. Chem. Soc. 126, 4828-4842. doi: $10.1021 /$ ja037980i

Kobayashi, H., Misawa, T. Matsuno, K., and Demizu, Y. (2017). Preorganized cyclic $\alpha, \alpha$-disubstituted $\alpha$-amino acids bearing functionalized side chains that act as peptide-helix inducers. J. Org. Chem. 82, 10722-10726. doi: 10.1021/acs.joc.7b01946

Konda, M., Jadhav, R. G., Maiti, S., Mobin, S. M., Kauffmannb, B., and Das, A. K. (2018). Understanding the conformational analysis of gababutin based hybrid peptides. Org. Biomol. Chem. 16, 1728-1735. doi: 10.1039/C8OB00035B

Kong, J., and $\mathrm{Yu}, \mathrm{S}$. (2007). Fourier transform infrared spectroscopic analysis of protein secondary structures. Acta Biochim. Biophys. Sinica. 39, 549-559. doi: 10.1111/j.1745-7270.2007.00320.x

Kozikowski, A. P., and Park, P. U. (1990). Synthesis of streptazolin: use of the aza-Ferrier reaction in conjunction with the INOC process to deliver a unique but sensitive natural product J. Org. Chem. 55, 4668-4682. doi: 10.1021/jo00302a036

Krishna, Y., Sharma, S., Ampapathi, R. S., and Koley, D. (2014). Furan-based locked $Z$-vinylogous $\gamma$-amino acid stabilizing protein $\alpha$-turn in water-soluble cyclic $\alpha 3 \gamma$ tetrapeptides. Org. Lett. 16, 2084-2087. doi: 10.1021/ol5002126

Laursen, J. S., Engel-Andreasen, J., Fristrup, P., Harris, P., Olsen, C. A. (2013). Cis-trans amide bond rotamers in $\beta$-peptoids and peptoids: evaluation of stereoelectronic effects in backbone and side chains. J. Am. Chem. Soc. 135, 2835-2844. doi: 10.1021/ja312532x

López-Andarias, A., López-Andarias, J., Atienza, C., Chichón, F. J., Carrascosa, J. L., and Martín, N. (2018). Tuning optoelectronic and chiroptic properties of peptide-based materials by controlling the pathway complexity. Chem. Eur. J. 24, 7755-7760. doi: 10.1002/chem.201801238

Machetti, F., Ferrali, A., Menchi, G., Occhiato, E. G., and Guarna, A. (2000). Oligomers of enantiopure bicyclic $\gamma / \delta$-amino acids (BTAa). 1. Synthesis and conformational analysis of 3-aza-6,8-dioxabicyclo[3.2.1] octane-7-carboxylic acid oligomers (PolyBTG). Org. Lett. 2, 3987-3990. doi: 10.1021/ol006548s

Memeo, M. G., Bruschi, M., Bergonzi, L., Desimoni, G., Faita, G., and Quadrelli, P. (2018). Cyclopenta[d]isoxazoline $\beta$-turn mimics: synthetic approach, turn driving force, scope, and limitations. ACS Omega 3, 13551-13558. doi: 10.1021/acsomega.8b01670 
Mikhalevich, V., Craciun, I., Kyropoulou, M., Palivan, C. G., and Meier, W. (2017). Amphiphilic peptide self-assembly: expansion to hybrid materials. Biomacromolecules 18, 3471-3480. doi: 10.1021/acs.biomac.7b00764

Pavone, V., Gaeta, G., Lombardi, A., Nastri, F., Maglio, O., Isernia, C., et al. (1996). Discovering protein secondary structures: classification and description of isolated $\alpha$-turns. Biopolymers 38, 705-721. doi: 10.1002/(SICI) 1097-0282(199606)38:6\&lt;705::AID-BIP3\&gt;3.0.CO;2-V

Pellegrino, S., Bonetti, A., Clerici, F., Contini, A., Moretto, A., Soave, R., et al. (2015). 1H-azepine-2-oxo-5-amino-5-carboxylic acid: a 310 helix inducer and an effective tool for functionalized gold-nanoparticles. J. Org. Chem, 80, 5507-5516. doi: 10.1021/acs.joc.5b00396

Pellegrino, S., Contini, A., Clerici, F., Gori, A., Nava, D., and Gelmi, M. L. (2012). 1H-Azepine-4-amino-4-carboxylic acid: a new $\alpha, \alpha$ disubstituted ornithine analogue capable of inducing helix conformations in short Ala-Aib pentapeptides. Chem. Eur. J. 18, 8705-8715. doi: 10.1002/chem.201104023

Pellegrino, S., Contini, A., Gelmi, M. L., Lo Presti, L., Soave, R., and Erba, E. (2014). Asymmetric modular synthesis of a semirigid dipeptide mimetic by cascade cycloaddition/ring rearrangement and borohydride reduction. J. Org. Chem, 79, 3094-3102. doi: 10.1021/jo500237j

Pellegrino, S., Facchetti, G., Contini, A., Gelmi, M. L., Erba, E., Gandolfi, R., et al. (2016). Ctr-1 Mets7 motif inspiring new peptide ligands for $\mathrm{Cu}(\mathrm{I})$-catalyzed asymmetric Henry reaction under green conditions. RSC Adv. 6, 71529-71533. doi: 10.1039/C6RA16255J

Pellegrino, S., Tonali, N., Erba, E., Kaffy, J., Taverna, M., Contini, A., et al. (2017). B-Hairpin mimics containing a piperidine-pyrrolidine scaffold modulate the ß-amyloid aggregation process preserving the monomer species. Chem. Sci. 8, 1295-1302. doi: 10.1039/C6SC03176E

Pinto, A., Conti, P., Grazioso, G., Tamborini, L., Madsen, U., Nielsen, B., et al. (2011). Synthesis of new isoxazoline-based acidic amino acids and investigation of their affinity and selectivity profile at ionotropic glutamate receptors. Eur. J. Med.Chem. 46, 787-793. doi: 10.1016/j.ejmech.2010.12.020

Pinto, A., Tamborini, L., Cullia, G., Conti, P., and De Micheli, C. (2016a). Inspired by nature: the 3-halo-4,5-dihydroisoxazole moiety as a novel molecular warhead for the design of covalent inhibitors. ChemMedChem 1, 10-14. doi: $10.1002 / \mathrm{cmdc} .201500496$

Pinto, A., Tamborini, L., Pennacchietti, E., Coluccia, A., Silvestri, R., Cullia, G., et al. (2016b). Bicyclic $\gamma$-amino acids as inhibitors of $\gamma$ aminobutyrate aminotransferase. J. Enzyme Inhib. Med. Chem. 2, 295-301. doi: $10.3109 / 14756366.2015 .1021251$

Raymond, D. M., and Nilsson, B. L. (2018). Multicomponent peptide assemblies. Chem. Soc. Rev. 47, 3659-3720. doi: 10.1039/C8CS00115D

Smith, E. L., and Spackman, D. H. (1955). Leucine aminopeptidase. V. activation, specificity, and mechanism of action. J. Biol. Chem. 122, 271-299.

Sohora, M., Vazdar, M., Sović, I., Mlinarić-Majerski, K., and Basarić, N. (2018). Photocyclization of tetra- and pentapeptides containing adamantylphthalimide and phenylalanines: reaction efficiency and diastereoselectivity. J. Org. Chem. 83, 14905-14922. doi: 10.1021 /acs.joc. 8 b01785

Solomon, L. A., Kronenberg, J. B., and Fry, H. C. (2017). Control of heme coordination and catalytic activity by conformational changes in peptide-amphiphile assemblies. J. Am. Chem. Soc. 139, 8497-8507. doi: $10.1021 /$ jacs.7b01588
Sperry, J. B., and Wright, D. L. (2005). Furans, thiophenes and related heterocycles in drug discovery. Curr. Opin. Drug Discov. Dev. 8, 723-740. doi: $10.1002 /$ chin. 200615242

Steinke, D., and Kula, M. R. (1990). Selektive desamidierung von peptidamiden. Angew Chemie 102, 1204-1206. doi: 10.1002/ ange.19901021035

Tamborini, L., Mastronardi, F., Dall'Oglio, F., De Micheli, C., Nielsen, B., Lo Presti, L., et al. (2015). Synthesis of unusual isoxazoline containing $\beta$ and $\gamma$-dipeptides as potential glutamate receptor ligands MedChemComm 6 , 1260-1266. doi: 10.1039/C5MD00159E

Tonan, K., and Ikawa, S. (1996). Intramolecular hydrogen bonding and conformation of small peptides: variable-temperature FTIR study on $\mathrm{N}$ Acetyl-1-Pro-l-Leu-Gly-NH $\mathrm{NH}_{2}$ and related compounds. J. Am. Chem Soc. 118, 6960-6965. doi: 10.1021/ja953380a

Tribello, G. A., Bonomi, M., Branduardi, D., Camilloni, C., and Bussi, G. (2014). PLUMED 2: new feathers for an old bird. Comp. Phys. Comm. 185, 604-613. doi: $10.1016 /$ j.cpc.2013.09.018

Tsantali, G. G., Dimtsas, J., Tsoleridis, C. A., and Takakis, I. M. (2007). Preparation of sixteen 3-hydroxy-4- and 7-hydroxy-1-hydrindanones and 3-hydroxy4- and 8-hydroxy-1-hydroazulenones. Eur. J. Org. Chem. 2007, 258-265. doi: $10.1002 /$ ejoc.200600639

Van Der Spoel, D., Lindahl, E., Hess, B., Groenhof, G., Mark,A. E., and Berendsen, H. J. (2005). GROMACS: fast, flexible, and free. J. Comput. Chem. 26, 1701-1718. doi: $10.1002 /$ jcc.20291

Vasudev, P. G., Chatterjee, S., Shamala, N., and Balaram, P. (2011). Structural chemistry of peptides containing backbone expanded amino acid residues: conformational features of $\beta, \gamma$, and hybrid peptides. Chem. Rev. 111, 657-687. doi: $10.1021 / \mathrm{cr} 100100 \mathrm{x}$

Wang, L., Coric, P., Zhu, K., Liu, W.-Q., Vidal, M., Bouaziz, S., et al (2018). Synthesis and characterization of water-soluble macrocyclic peptides stabilizing protein $\alpha$-turn. Org. Biomol. Chem. 16, 459-471. doi: 10.1039/ C7OB02852K

Wintjens, R. T., Rooman, M. J., and Wodak, S. J. (1996). Automatic classification and analysis of alpha alpha-turn motifs in proteins. J. Mol. Biol. 255, 235-253. doi: $10.1006 /$ jmbi.1996.0020

Zhang, X. X., Eden, H. S., and Chen, X. (2012). Peptides in cancer nanomedicine: drug carriers, targeting ligands and protease substrates. J. Control Release 159, 2-13. doi: 10.1016/j.jconrel. 2011.10.023

Conflict of Interest Statement: The authors declare that the research was conducted in the absence of any commercial or financial relationships that could be construed as a potential conflict of interest.

Copyright (c) 2019 Oliva, Bucci, Tamborini, Pieraccini, Pinto and Pellegrino. This is an open-access article distributed under the terms of the Creative Commons Attribution License (CC BY). The use, distribution or reproduction in other forums is permitted, provided the original author(s) and the copyright owner(s) are credited and that the original publication in this journal is cited, in accordance with accepted academic practice. No use, distribution or reproduction is permitted which does not comply with these terms. 